\title{
Manajemen Referensi dengan Aplikasi Zotero
}

\author{
Muhammad Kasim Aidid ${ }^{1}$, M. Nadjib Bustan ${ }^{2}$, Ruliana ${ }^{3}$ \\ ${ }^{1,2,3}$ Prodi Statistika, FMIPA Universitas Negeri Makassar
}

\begin{abstract}
Based on the situation analysis, a Community Partnership Program (PKM) activity is proposed to train the use of reference management software for teachers in which SMA Negeri 4 Pinrang Regency is the partner. The identified problems are: (1) Lack of skills in using reference manager software, (2) Zotero as open source software is unknown, (3) The need for the ability to use reference manager software that can be applied in writing scientific papers. The material is presented through zoom meetings in plenary and in groups according to the schedule. In the plenary presentation of the material, material on basic concepts in research and writing of scientific papers was presented then continued with the provision of material on the use of Zotero in writing scientific articles. Some of the requirements to become a participant are: (1) having an interest in learning the basic concepts of reference management, (2) having never attended a similar training. (3) must attend all training activities. From the PKM activities that have been carried out as well as the team's internal survey, it can be concluded that in the implementation of this activity: (1) Participants become literate and skilled in operating the Zotero software, (2) The Zotero menu is well known to PKM participants, (3) Participants have the ability to use Zotero in writing scientific articles.
\end{abstract}

Keywords: Reference Manager, Zotero, Skilled

\section{PENDAHULUAN}

Aktifitas publikasi ilmiah merupakan salah satu komponen kegiatan yang sangat penting dari keseluruhan kegiatan seorang pengajar baik guru maupun dosen. Dalam kegiatan publikasi ilmiah, pengutipan terhadap suatu sumber referensi adalah bagian yang tidak terpisahkan yang membutuhkan usaha besar dalam mengumpulkan dan mengorganisasinya. Kegiatan mengumpulkan sumber referensi, membaca, dan memasukkannya ke dalam naskah sebagai kutipan merupakan pekerjaan yang sangat menyita waktu dan tenaga. Perangkat lunak reference manager merupakan tool yang berperan efisien dalam melakukan digitalisasi koleksi referensi, sehingga aktifitas seperti pengelolaan dan pencarian dapat dengan mudah dilakukan (Marshall, 2020; Ray, 2017). Saat ini telah banyak pilihan perangkat lunak reference manager yang popular diantaranya bersifat open source seperti zotero.

Menurut Fenner (2010), reference manager membantu peneliti dengan melakukan tiga fungsi dasar yaitu pencarian (searching), penyimpanan (storing), dan penulisan (writing). Sehingga dalam aktifitas yang terkait dengan publikasi ilmiah dimungkinkan mencari sumber referensi yang diperlukan, menyimpan dan mengorganisasi sumber referensi dan informasi bibliografi dalam basis data, serta mempermudah dalam penulisan pengutipan dan daftar referensi dengan mengikuti gaya selingkung yang sesuai, misal Chicago, IEEE, APA, dll. Perangkat lunak reference manager melayani berbagai fungsi (Gilmour \& Cobus-Kuo, 2011), Secara umum dapat: 1). mengimpor kutipan dari database bibliografi dan situs web, (2) mengumpulkan metadata dari file PDF, (3). mengorganisasi kutipan dalam database, (4). melakukan anotasi kutipan, (5). berbagi database atau bagiannya dengan kolega, (6). mengizinkan pertukaran data dengan software lainnya melalui format metadata standar (mis., RIS, BibTeX), (7). membuat kutipan dalam berbagai gaya selingkung, (8). bekerja dengan perangkat lunak pengolah kata untuk memfasilitasi kutipan dalam teks.

Sesuai dengan berbagai keputusan yang berkaitan dengan pengembangan keterampilan, maka sebagai wujud pengabdian pada masyarakat dalam upaya membantu pengembangan pengetahuan dan pemahaman tentang penggunaan 
software reference manager, maka kegiatan pelatihan dilakukan sebagai bagian dari kepedulian dalam mengembangkan misi pengembangan kemampuan professional dalam melakukan kegiatan penelitian dan publikasi (Idri, 2015). Pelaksanaan kegiatan ini menyangkut pemberian penjelasan tentang prosedur penggunaan sofware zotero. Zotero adalah aplikasi yang mendukung situs web penelitian utama seperti ISI Web of Knowledge, Google Scholar, PubMed, banyak situs jurnal dan surat kabar, dan katalog perpustakaan universitas (Murimboh \& Hollingdale, 2012). Berdasarkan analisis situasi yang dikemukakan, kemudian diusulkan kegiatan pelatihan pemanfaatan software manajemen referensi pada guru-guru dimana SMA Negeri 4 Kabupaten Pinrang sebagai mitra.

Permasalahan mitra diindetifikasi sebagai berikut:

1. Kurangnya keterampilan dalam menggunakan software reference manager

2. Zotero sebagai software open source yang bebas lisensi belum dikenal.

Perlunya kemampuan penggunaan software reference manager yang dapat diaplikasikan dalam penulisan karya tulis ilmiah.

\section{METODE YANG DIGUNAKAN}

1. Memperkenalkan Zotero sebagai software open source yang bebas lisensi, mulai dari laman web, proses download sampai pada instalasi perangkat lunak.

2. Memperkenalkan menu pada Zotero dan kelebihan yang dimiliki paket tersebut.

3. Memberikan pelatihan Penggunaan Zotero dalam penulisan artikel ilmiah.

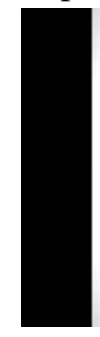

\section{Research Design:}

Using Mixed

Methods

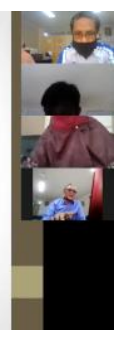

Gambar 1. Materi pengantar metode penelitian
Materi dipresentasikan melalui zoom meeting secara pleno dan secara kelompok sesuai dengan jadwal. Dalam presentasi materi secara pleno, disajikan materi tentang konsep dasar dalam penelitian serta penulisan karya ilmiah kemudian dilanjutkan dengan pemberian materi tentang penggunaan Zotero dalam penulisan artikel ilmiah. beberapa persyaratan untuk menjadi peserta ditetapkan sebagai berikut: (1) peserta memiliki minat dalam mempelajari konsep dasar manajemen referensi, (2). belum pernah mengikuti pelatihan serupa. (3). peserta diwajibkan mengikuti seluruh kegiatan pelatihan.

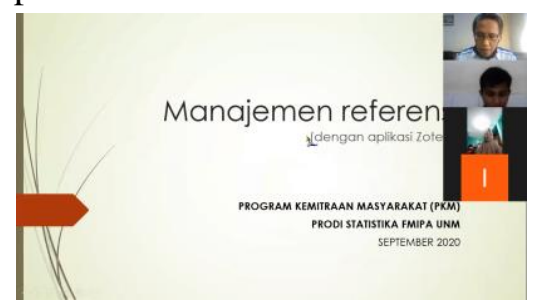

Gambar 2. Memulai pelatihan manajemen referensi

\section{PELAKSANAAN DAN HASIL KEGIATAN}

\section{A. Pengenalan dan instalasi Zotero}

Melalui dialog singkat diketahui bahwa keseluruhan peserta pelatihan belum pernah sama sekali menggunakan aplikasi reference manager dalam penulisan karya ilmiahnya. Oleh karena itu, diberikan pengenalan aplikasi yang lebih detail (gambar 2) termasuk Langkah-langkah instalasinya.

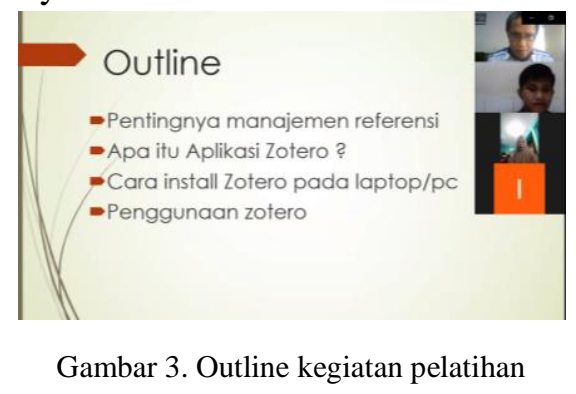

\section{B. Eksplorasi menu Zotero}

Setelah peserta disuguhi materi pengenalan dan proses instalasi aplikasi Zotero, maka tahapan selanjutnya adalah mengeksplorasi menu serta melakukan pencarian serta pengoleksian referensi ke dalam aplikasi. Pada tahapan ini peserta 
dituntun untuk menambah referensi secara manual dan juga secara online. Berbagai fasilitasi pada Zotero dikenalkan seperti menambah berbagai buku, artikel serta berbagai referensi lainnya pada menu new item. Peserta juga dituntun menggunakan add item(s) by identifier untuk menambah referensi menggunakan ISBN, DOI, PMID, dan Arciv.id. menu lain yang digunakan untuk menambah referensi adalah add attachement melalui penggunaan link dan copy file.

\section{(4) $+8.0+10$}

Title

Gambar 5. Menu new item, add item(s) by identifier, dan add attachement.

\section{Penggunaan Zotero dalam Penulisan Artikel Ilmiah}

Zotero sebagai aplikasi reference manager sangat handal digunakan dalam mengumpulkan, mengorganisasi, melakukan sitasi dan berbagai hasil riset. Pada sesi ini, didemonstrasikan bagaimana melakukan kutipan dan penulisan bibliografi serta bagaimana beralih dari satu gaya selingkung ke gaya selingkung yang lain.

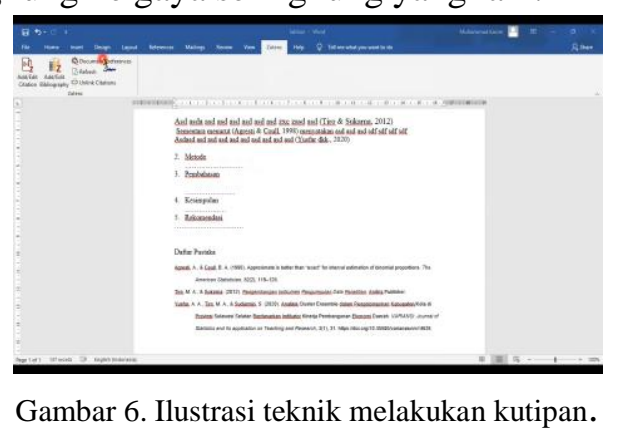

Peserta dituntun pula mencari style (gaya selingkung) yang tersedia secara online di zotero.

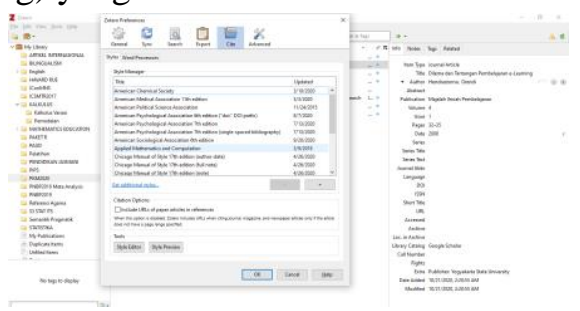

Gambar 7. Pemilihan citation style.

\section{KESIMPULAN}

Dari kegiatan PKM yang telah dilakukan serta survei internal tim, maka dapat disimpulkan bahwa pada pelaksanaan kegiatan ini:

1. Peserta menjadi melek dan terampil dalam mengoperasikan software Zotero

2. Menu Zotero sebagai software open source yang bebas lisensi dikenal dengan baik oleh peserta PKM di SMA Negeri 4 Kab. Pinrang.

3. Peserta memiliki kemampuan penggunaan Zotero dalam penulisan artikel ilmiah.

\section{UCAPAN TERIMA KASIH}

Ucapan terima kasih disampaikan kepada Ketua Lembaga Pengabdian Kepada Masyarakat UNM dan Kepala Sekolah serta Guru SMA Negeri 4 Kabupaten Pinrang, sehingga kegiatan PKM ini dapat terlaksana walaupun dalam kondisi pandemic covid-19.

\section{DAFTAR PUSTAKA}

Fenner, M. (2010). Reference management meets Web 2.0. Cell Ther Transplant, 2(6), 1-3.

Gilmour, R., \& Cobus-Kuo, L. (2011). Reference management software: A comparative analysis of four products. Issues in science and technology librarianship, 66(66), 63-75.

Idri, N. (2015). Zotero Software: A Means of Bibliographic Research and Data Organisation; Teaching Bibliographic Research. SSRN Electronic Journal. https://doi.org/10.2139/ssrn.2843984

Marshall, C. (2020). Citation Management Software Raises Library Profile. Journal of Hospital Librarianship, 20(2), 151-155. https://doi.org/10.1080/15323269.2020.173885 0

Murimboh, J. D., \& Hollingdale, C. R. (2012). Zotero: A Reference Manager for Everyone. Journal of Chemical Education, 89(1), 173174. https://doi.org/10.1021/ed1010618

Ray, A. K. (2017). Zotero: Open Source Citation Management Tool for Researchers. 8. 